\title{
Identification and characterization of two amylase producing bacteria Cellulosimicrobium sp. and Demequina sp. isolated from marine organisms
}

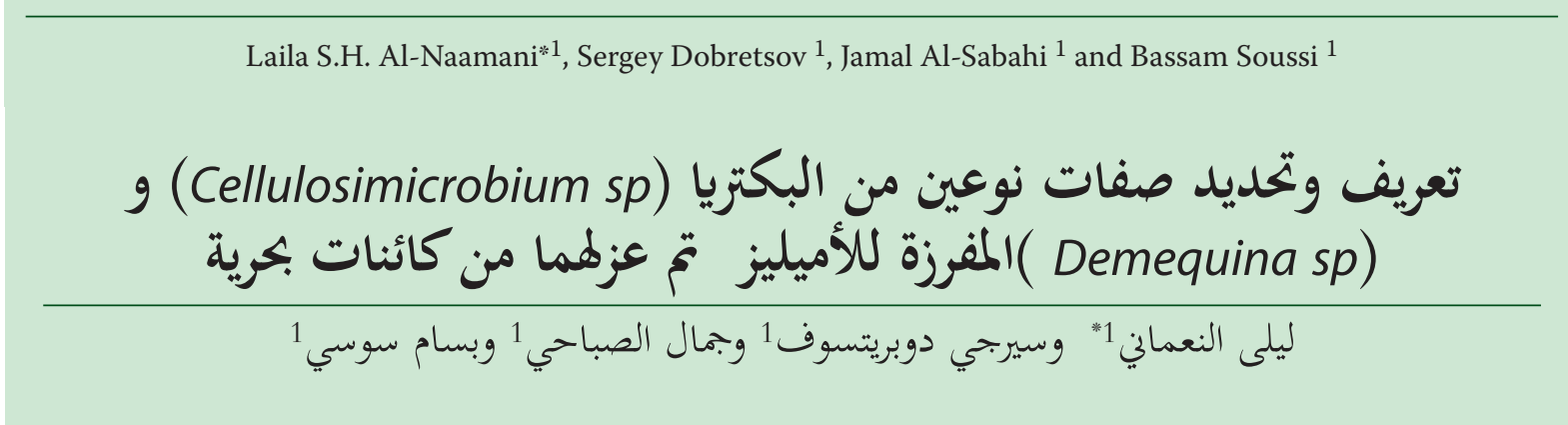

ABSTRACT. Marine sources have been known to yield novel compounds with a wide range of bioactivity with various commercial applications. In this study, the abilities of bacteria isolated from eight marine organisms to produce $\alpha$-amylase were examined. All eight organisms were found to harbor amylase producing bacteria. Two bacterial species isolated from the green alga Ulva rigida and the sponge Mycale sp. were further identified and their $\alpha$-amylases were purified and characterized. The bacterial species isolated from $U$. rigida and Mycale sp. were identified by DNA sequencing as Cellulosimicrobium sp. and Demequina sp., respectively. Cellulosimicrobium sp. obtained maximum cell growth and amylase production at $29^{\circ} \mathrm{C}$ and in the presence of lactose as a carbon source. Optimal cell growth and amylase production by Demequina sp. was observed at $35^{\circ} \mathrm{C}$. While lactose enhanced cell growth of Demequina sp., maximum amylase production was found when fructose and glycerol were the available sources of carbon. Both strains grew better in the presence of tryptone, whilst peptone stimulated amylase production. Maximal cell growth and amylase production by both of the strains was found at a medium salinity of $3 \% \mathrm{NaCl}$.

KEYWORDS: Natural products, enzymes, amylase, bacteria.

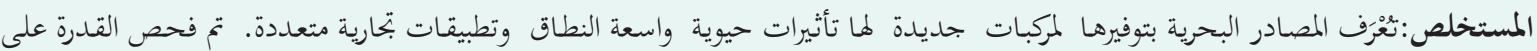

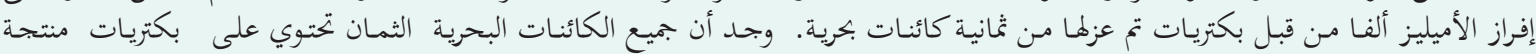

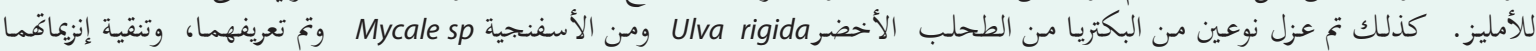

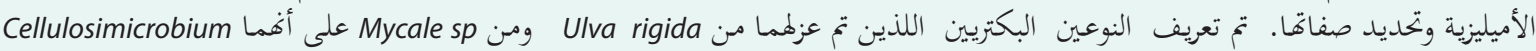

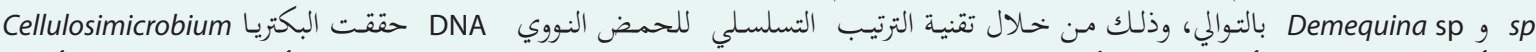

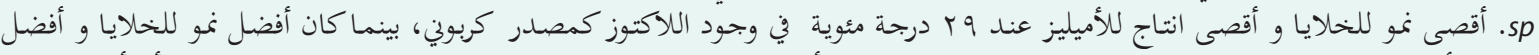

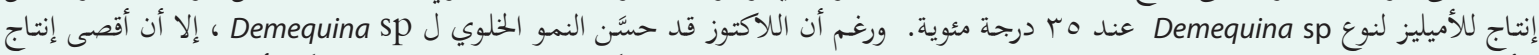

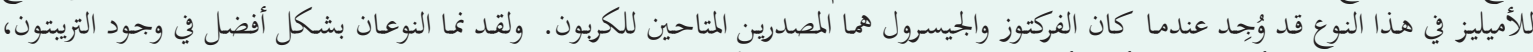

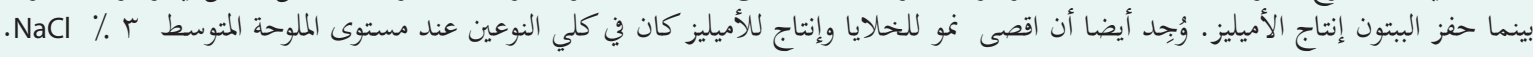
الكلمات المفتاحية: المنتجات الطبيعية،الأنيمات، الأميليز

\section{Introduction}

$\mathrm{T}$ he sea is a unique resource with a large diversity of natural products isolated mainly from invertebrates, such as sponges, tunicates, bryozoans and molluscs, as well as from bacteria (Proksch et al., 2002). Symbiotic microorganisms are often proposed as the true producers of natural products isolated from marine invertebrates. Numerous examples exist in

1* Laila S.H. Al-Naamani ( $\longrightarrow$ ) Sultan Qaboos University, College of Agricultural and Marine Sciences, Dept. of Marine Science and Fisheries, Box 34, Al-Khod 123, Sultanate of Oman. email: p029787@student. squ.edu.om. which structurally related or identical compounds have been reported from taxonomically distinct invertebrates and cultured microorganisms (Moore, 1999; Proksch et al., 2002). Recently, research has focused on marine microorganisms as sources of many metabolites that have a potential to be used as antibiotics, antimicrobials, or antitumor agents and pharmaceuticals.

Marine microorganisms are a valuable source of novel enzymes with ideal characteristics because of the halophilic nature of the marine bacteria (Mohapatra et al., 1998). Halophiles are microorganisms that live, grow, and multiply in highly saline environments. Moderately halophilic bacteria are able to grow over a wide range of salt concentrations from 0.4 to $3.5 \mathrm{M}$. Exoenzymes from 
these microorganisms with polymer degrading ability at low water activities are of interest in many harsh industrial processes where concentrated salt solutions would inhibit many enzymatic conversions. Furthermore, most halobacterial enzymes are known to be thermotolerant and remain stable at room temperature for a long time (Chakraborty et al., 2008(b); Mohapatra et al., 1998).

Free-living bacteria and bacteria attached to marine sediments usually excrete large amounts of extracellular enzymes for the hydrolysis of intractable macromolecules (Mohapatra et al., 2003). The enzymes secreted by the bacteria remain associated with the cell and are released slowly to the environment to aid in the nutrition of their host. Until now, researchers have isolated several enzymes such as acetylcholinesterase, amylase, urethanase, cellulase, and alginate and pectin lyases from bacteria and fungi associated with marine sponges and algae (Mohapatra et al., 2003). Although many microorganisms produce amylase, the ones most commonly used for industrial production are Bacillus subtilis, Bacillus licheniformis, Bacillus amyloliquifaciens and Aspergillus niger (Vidyalakshmi, 2009).

The sea around Oman is rich in marine organisms that could be a potential source of natural products that are not yet exploited. The overall objectives of this study was to isolate bacteria associated with Omani marine organisms, study their abilities to produce amylase and to investigate the optimal conditions (temperature, $\mathrm{pH}$ and salinity, carbon and nitrogen sources) for bacterial growth and enzyme production.

\section{Materials and methods}

\section{Isolation of pure cultures from marine environ- ments}

Samples from eight marine organisms: the red sponge Mycale sp., the tunicate red Ascidia sp., the tunicate black Ascidia nigra, the whitesponge Chalina sp., the yellow sponge Hemiasterella sp., the sea anemone Heteractis crispa and the green alga Ulva rigida and sea water were collected from Bandar Al Khairan (depth 1-5 m), Arabian Gulf, Sultanate of Oman. The marine organisms were transferred into plastic bags immediately after collection and kept in ice until transferred to the laboratory. In the laboratory, the samples were transferred to conical flasks containing marine broth and placed in a rotary shaker at $180 \mathrm{rpm}$ at $29 \mathrm{oC}$ for about 24 to 48 hours. After incubation, a loop full of each sample mixture was streaked onto nutrient agar and incubated for another 24 hours. The bacterial colonies were separated and subcultured several times until pure bacterial cultures were obtained.

\section{Screening of amylolytic enzymes production}

To check the amylolytic activity of the isolated bacterial strains, each pure bacterial culture was cultured in

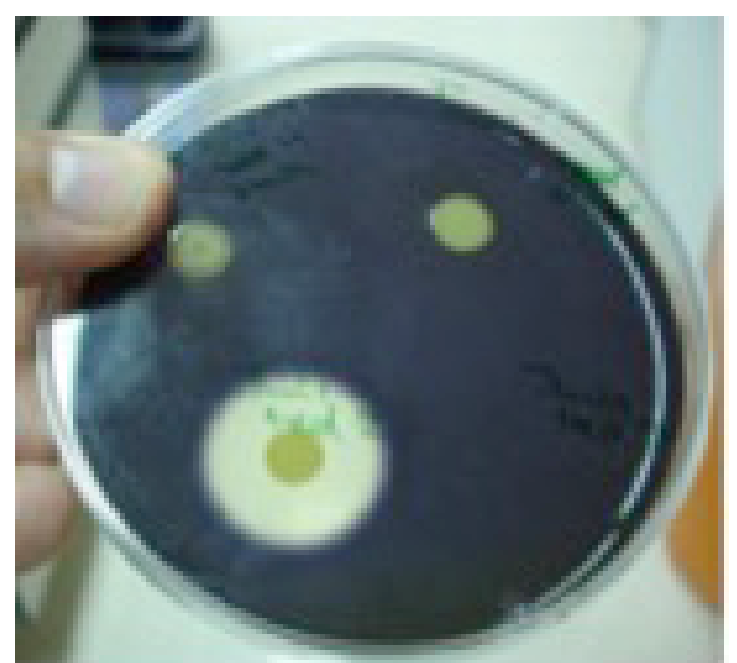

Figure 1. Starch hydrolysis by amylase producing bacteria visualized by Lugol's-iodine coloration.

marine broth and incubated for about 24 hours. Subsequently, about $20 \mu$ l of each bacterial culture was dropped on Starch agar and incubated for 24 to 48 hours. After incubation, amylase production was determined by the development of a colourless halo zone surrounding the bacterial colonies when Lugol's iodine solution (1\% iodine in $2 \%$ potassium iodide $\mathrm{w} / \mathrm{v}$ ) was added to the plate (Fig.1). The diameters of the digestion zones were measured to check the intensity of the enzyme activity of the bacteria. Two of the fastest growing bacteria with largest starch digestion zones were chosen for further identification and analysis.

\section{Bacterial identification}

The two bacterial strains were first identified by gram staining, API Coryne and negative staining (TEM test). Then, further identification was done by DNA sequencing and fatty acid analysis profile.

\section{DNA sequencing}

The bacterial strains were identified by comparative analysis of their 16S rRNA gene sequences as described in Lau et al., 2002. Fragments of DNA sequences (about $700 \mathrm{bp}$ ) obtained from individual primers were assembled using the Sequencher ${ }^{\circ}$ software package (Gene Codes, USA). The closest match to the 16S rDNA gene sequence of the respective bacteria was retrieved by comparison with data from the GenBank (www.ncbi. nlm.nih.gov).

\section{Bacterial fatty acids analysis}

The sample preparation and analysis for bacterial fatty acid determinations were performed as described by Sasser, 1990 using hexane mixed with methyl tert butyl ether for the extraction of the fatty acids from the bacterial strains. 

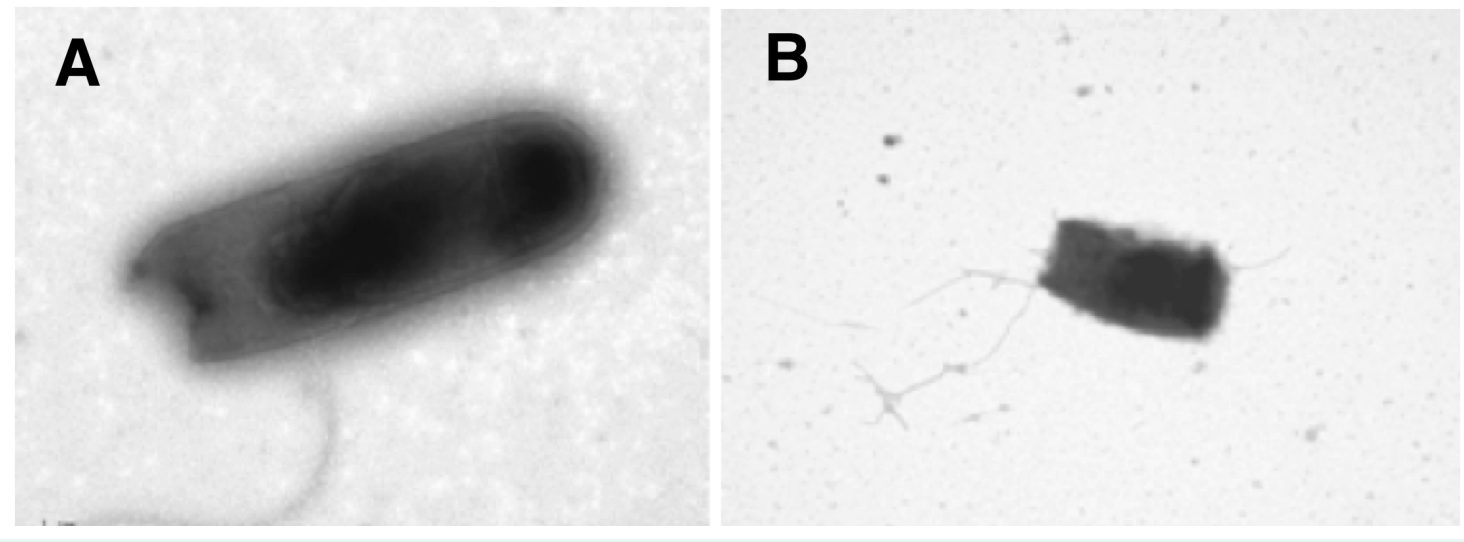

Figure 2. (a) Cellulosimicrobium sp. isolated from the green alga Ulva rigida after negative staining (TEM test) under electron microscope at 25000x magnifications. (b) Demequina sp. isolated from sponge Mycale sp. after negative staining (TEM test) under electron microscope at 15000x magnification.

\section{GC analysis}

One $\mu \mathrm{l}$ of each extract of bacterial fatty acids in hexane- methyl tert butyl ether mixture was injected into a Gas Chromatograph (Agilent $6890 \mathrm{~N}$ ) instrument equipped with Ultra-1 (crosslinked methyl silicone gum) column, HP catalogue No. 19091A-102 (25m long x $0.2 \mathrm{~mm}$ i.d x $0.33 \mu \mathrm{l}$ film thickness).

\section{Analytical conditions}

The injector and flame ionization detector (FID) temperatures were set at $250^{\circ} \mathrm{C}$ and $260^{\circ} \mathrm{C}$, respectively. The oven temperature was programmed from $150^{\circ} \mathrm{C}$ (2 minutes) to $250^{\circ} \mathrm{C}$ ( 5 minutes $)$ at $4^{\circ} \mathrm{C} / \mathrm{min}$. Helium was used as the carrier gas with a linear velocity of $20 \mathrm{~cm} / \mathrm{sec}$. The duration of the reaction was set for 40 minutes.

\section{Data analysis}

Retention times of the unknown bacterial fatty acids were compared to a mixture of standard bacterial fatty acid methyl esters (BAME) (Supelco, Catalogue No. 47080).

\section{Sensitivity of bacterial strains to antibiotics}

The bacterial strains were tested for their susceptibility to the following antibiotics: Ampicillin, Streptomycin, Chloramphenicol, and Penicillin G. Concentrations of 1 $\mathrm{mg} / \mathrm{ml}$ and $10 \mathrm{mg} / \mathrm{ml}$ were used for each antibiotic. The test was performed using a disc diffusion bioassay.

The bacterial colonies of the two strains were evenly distributed on nutrient agar using sterile swabs. Small discs (diameter $=5.5 \mathrm{~mm}$ and surface area $=1 \mathrm{~cm} 2$ ) containing each type of antibiotic were placed in the media inoculated with bacteria and incubated for about 24 hours. Presence of clear zones around the discs correspondent to the bacterial growth inhibition was checked and their diameters were measured in millimetres with a ruler.

\section{Optimization of bacterial yield and amylase Production}

The effect of temperature, salinity and available carbon and nitrogen sources on bacterial growth was tested by measuring the optical density of the samples after incubation. Amylase production was determined by the amount of maltose produced as an end product of starch hydrolysis by amylase.

\section{Bacterial yield test}

Marine broth containing different $\mathrm{NaCl}$ concentration $(0 \%, 3 \% 5 \%, 10 \%$ and $15 \%(\mathrm{w} / \mathrm{v}))$ were prepared to test the effect of salinity. Solutions containing $1 \%$ of a specific carbon source namely starch, glucose, fructose, lactose, glycerol, sucrose or maltose along with $0.1 \%$ yeast extract were prepared in sea water. Solutions containing $1 \%$ peptone or tryptone as nitrogen sources were also prepared and supplemented with $0.1 \%$ yeast extract mixed with sea water. Test tubes containing $10 \mathrm{ml}$ of each solution was inoculated with the bacterial cultures except the blank and incubated at $29^{\circ} \mathrm{C}$ for $24 \mathrm{~h}$. To test the effect of temperature, test tubes containing $10 \mathrm{ml}$ marine broth inoculated with the bacterial cultures were incubated at different temperatures $\left(5^{\circ} \mathrm{C}, 29^{\circ} \mathrm{C}, 35^{\circ} \mathrm{C}\right.$ and $60^{\circ} \mathrm{C}$ ) for $24 \mathrm{~h}$. After incubation, the blank control was used to zero the spectrophotometer and the absorbance at $600 \mathrm{~nm}$ was measured for all the samples.

\section{Determination of bacterial amylase production}

The culture solutions prepared in the bacterial yield test, as above, were centrifuged at 10,000 rpm for 5 minutes at $15^{\circ} \mathrm{C}$ to separate the bacterial cells from the broth. 1 $\mathrm{ml}$ of cell free supernatant of each sample was removed and added to tubes containing $1 \mathrm{ml}$ of $1 \%$ starch solution. $1 \mathrm{ml}$ of distilled water with $1 \mathrm{ml}$ of $1 \%$ starch solution was added to the blank tube. The tubes were incubated at $37 \mathrm{oC}$ for 12 minutes. After incubation, $1 \mathrm{ml}$ of maltose colour reagent (1\% 3,5-dinitrosalicylic acid, 
Table 1. Results of gas chromatography mass spectrometry (GC-MS) analysis.

\begin{tabular}{|c|c|c|c|c|}
\hline & BAME name & $\begin{array}{l}\text { Ret. } \\
\text { (Min) }\end{array}$ & $\mathrm{Cm}$ & $\mathrm{Dq}$ \\
\hline 1 & Methyl Dodecanoate (C12:0) & 17.42 & 0.24 & 1.9 \\
\hline 2 & Methyl tridecanoate (C13:0) & 20.05 & 0.31 & 0.0 \\
\hline 3 & $\begin{array}{l}\text { Methyl } 2 \text { Hydroxydodeca- } \\
\text { noate } \\
(2-\mathrm{OH}-\mathrm{C} 12: 0)\end{array}$ & 20.38 & 0.05 & 0.0 \\
\hline 4 & $\begin{array}{l}\text { Methyl 3-hydroxydecanoate } \\
(3-\mathrm{OH}-\mathrm{C} 12: 0)\end{array}$ & 21.03 & 2.70 & 1.7 \\
\hline 5 & $\begin{array}{l}\text { Methyl tetradecanoate } \\
\text { (C14:0) }\end{array}$ & 22.67 & 8.01 & 4.8 \\
\hline 6 & $\begin{array}{l}\text { Methyl 13-methyltetradeca- } \\
\text { noate (i-C15:0) }\end{array}$ & 24.32 & 1.22 & 3.2 \\
\hline 7 & $\begin{array}{l}\text { Methyl 12-methyltetradeca- } \\
\text { noate }(\alpha-C 15: 0)\end{array}$ & 24.53 & 0.16 & 0.0 \\
\hline 8 & $\begin{array}{l}\text { Methyl pentadecanoate } \\
\text { (C15:0) }\end{array}$ & 25.22 & 2.84 & 2.2 \\
\hline 9 & $\begin{array}{l}\text { Methyl 3-hydroxytetradeca- } \\
\text { noate (3-OH-C14:0) }\end{array}$ & 26.22 & 4.82 & 3.7 \\
\hline 10 & $\begin{array}{l}\text { Methyl 14-methylpentadeca- } \\
\text { noate (i-C16:0) }\end{array}$ & 26.81 & 1.94 & 0.7 \\
\hline 11 & $\begin{array}{l}\text { Methyl cis-9-hexadecenoate } \\
\text { (C16:19) }\end{array}$ & 27.16 & 39.52 & 29.8 \\
\hline 12 & $\begin{array}{l}\text { Methyl hexadecanoate } \\
\text { (C16:0) }\end{array}$ & 27.68 & 15.24 & 16.4 \\
\hline 13 & $\begin{array}{l}\text { Methyl 15-methylhexadeca- } \\
\text { noate } \\
\text { (i-C17:0) }\end{array}$ & 29.22 & 1.58 & 6.6 \\
\hline 14 & $\begin{array}{l}\text { Methyl heptadecanoate } \\
\text { (C17:0) }\end{array}$ & 30.1 & 1.27 & 1.3 \\
\hline 15 & $\begin{array}{l}\text { Methyl trans-9-octadece- } \\
\text { noate (C18:19) }\end{array}$ & 32.17 & 19.85 & 26.7 \\
\hline 16 & $\begin{array}{l}\text { Methyl octadecanoate } \\
\text { (C18:0) }\end{array}$ & 32.77 & 0.24 & 0.4 \\
\hline
\end{tabular}

0.4 $\mathrm{M} \mathrm{NaOH}, 1.06 \mathrm{M}$ sodium potassium tartrate) was added to each tube and heated for $15 \mathrm{~min}$ at $100^{\circ} \mathrm{C}$. The heated mixtures were cooled immediately in ice. Then, 9 $\mathrm{ml}$ distilled water was added to each tube. The blank was used to zero the spectrophotometer and the absorbance at $540 \mathrm{~nm}$ was measured for all the samples.

\section{Results}

\section{Bacterial isolation and enzyme screening}

All eight organisms tested were found to harbour enzyme producing bacteria. More than 150 species of marine bacteria were isolated and more than 50 species were screened for enzyme production (Figure 1). Pure colonies have been isolated and two species among the fastest growing strains with the highest ability to hydrolyze starch were selected from the green alga Ulva rigida (Strain I) and the red sponge Mycale sp. (Strain II).

\section{Bacterial strain identification}

The two strains showed characteristics of being Gram positive. According to API Coryne test, Strain I was identified from the ApiwebTM identification software as Cellulosimicrobium cellulans with $87.3 \%$ accuracy whereas Strain II was identified as Cellulomonas spp. with 99.9\% accuracy. According to partial 16S RNA sequences, the two bacterial strains were identified as follows:

Strain I: Cellulosimicrobium sp. with 98\% accuracy (Bacteria; Actinobacteria; Actinobacteridae; Actinomycetales; Micrococcineae; Promicromonosporaceae)

Strain II: Demequina sp. with 98\% accuracy (Bacteria; Actinobacteria; Actinobacteridae; Actinomycetales; Micrococcineae; Cellulomonadaceae)

The TEM showed the structure of the two strains under different magnifications (Figure 2). Gas chromatographic analysis showed that the two bacterial strains had quite similar fatty acid compositions except for the absence of three types of bacterial fatty acids in Demequina sp. (Table 1). This can be explained by fact that genes Cellulosimicrobium and Demequina are highly similar. Previously Demequina was re-classified from Cellulomonas (Yi et al., 2007; Ue et al. 2011). This fact supports our API Coryne test data that identified strain II as Cellulomonas sp.

\section{Susceptibility to antibiotics}

Both of the strains were highly susceptible to Chloramphenicol at concentrations of $1 \mathrm{mg} / \mathrm{ml}$ and $10 \mathrm{mg} / \mathrm{ml}$ with larger inhibition zones, specifically diameters of $30 \pm 2.8 \mathrm{~mm}$ and $32.5 \pm 3.5 \mathrm{~mm}$ for Cellulosimicrobium sp. and Demequina sp., respectively, at a concentration of $10 \mathrm{mg} / \mathrm{ml}$. The two bacterial isolates were inhibited by $10 \mathrm{mg} / \mathrm{ml}$ Streptomycin whereas they were not affected by the same antibiotic at the lower concentration of 1 $\mathrm{mg} / \mathrm{ml}$. No inhibitory effect on the growth of both isolates was observed by Ampicillin and Penicillin G.

The susceptibility of members of the genus Cellulomonas to different antibiotics was studied by Funke et al. (1995). All the clinical isolates of Cellulomonas species were found to be strongly susceptible to Ciprofloxacin, Clindamycin, Erythromycin and Gentamicin. However, they were less susceptible to Penicillin G, Rifampin, Tetracycline and Vancomycin.

It was found that the bacterium Cellulosimicrobium cellulans grew well on standard synthetic media and was susceptible to a variety of antibiotics, including Penicillin, Macrolides, and Glycopeptides (Heym, 2005). Yoon (2007) isolated Cellulosimicrobium terreum from soil and found it to be susceptible to Streptomycin (50 $\mu \mathrm{g})$, Chloramphenicol (100 $\mu \mathrm{g})$ and Penicillin G (20 U). Susceptibility to Ampicillin was observed by three clinical strains of Cellulosimicrobium funkei (Brown et al., 2006). All these results are totally different from what we obtained from Cellulosimicrobium sp. in our study, 


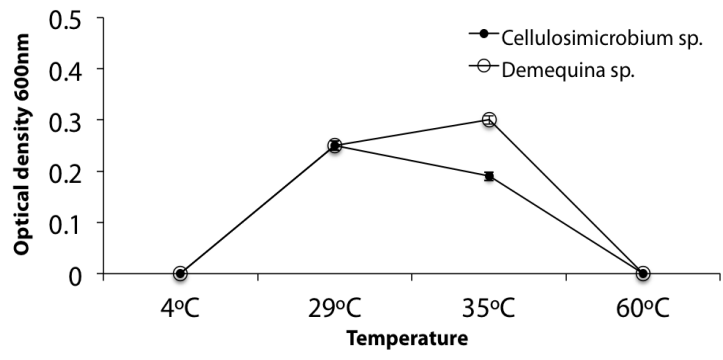

Figure 3. Effect of temperature on cell yield of Cellulosimicrobium sp. and Demequina sp. $(\lambda 600 \mathrm{~nm})$. The data are the means of two replicates \pm standard deviation.

since it was not affected by Ampicillin and Penicillin G and was susceptible to only higher concentrations of Streptomycin. Probably this was due to isolation of our novel strain from different environment (marine). Additionally, different antibiotic susceptibility could be due to antibiotic resistance of some bacterial strains (Brown et al., 2006).

\section{Bacterial yield and amylase production}

\section{Effect of temperature}

The results showed optimal temperature for cell growth and enzyme production between $29^{\circ} \mathrm{C}$ and $35^{\circ} \mathrm{C}$ for Cellulosimicrobium sp. and Demequina sp., respectively (Fig. 3 \& 4). The two strains were inactivated at $4^{\circ} \mathrm{C}$ and $60^{\circ} \mathrm{C}$ which indicates the mesophilic characteristics of the two bacterial strains. This property can be related to the natural habitat of the two bacterial strains in the mesophilic sea environment. This is in accordance with what was reported by Asgher et al. (2007) and Kathiresan and Manivannan (2006) that the influence of temperature on amylase production is related to the growth of the microorganism.

\section{Effect of salt concentration}

The highest bacterial growth and enzyme production for Cellulosimicrobium sp. and Demequina sp. was obtained

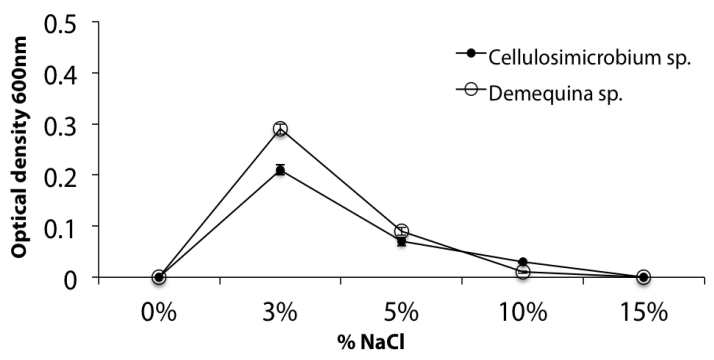

Figure 5. EEffect of salt concentration on cell yield of Cellulosimicrobium sp. and Demequina sp. ( $(2600 \mathrm{~nm})$. The data are the means of two replicates \pm standard deviation.

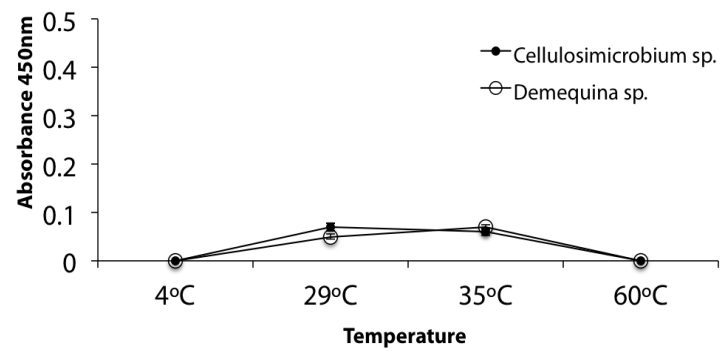

Figure 4. Effect of temperature on amylase production of Cellulosimicrobium sp. and Demequina sp. ( $\lambda 540 \mathrm{~nm})$. The data are the means of two replicates \pm standard deviation.

in the presence of $3 \% \mathrm{NaCl}(\mathrm{w} / \mathrm{v})$ (Fig. 5 \& 6), which is the normal salinity of sea water. These results might be related to the nature of the bacterial origin since they were isolated from marine environments. There was no amylase production in the absence of $\mathrm{NaCl}$ which clearly indicates the halophilic nature of the enzymes of both strains. Cellulosimicrobium sp. retained about $9 \%$ of its growth ability at $10 \%$ salt but both strains lost their enzyme productivity at this salinity. Prakash (2009b) reported that halophilic enzymes require high salt concentrations for their activity due to their adaptation to high salt concentrations while they undergo denaturation at $\mathrm{NaCl}$ concentrations below $1 \mathrm{M}$. He also suggested that halophilic bacteria can produce enzymes that can tolerate high salt concentrations $3-15 \% \mathrm{NaCl}$.

\section{Effect of carbon and nitrogen sources on bacterial yield and amylase production}

The maximum optical density and maltose production by Cellulosimicrobium sp. in the presence of lactose was observed (Figure 7). This indicated higher cell growth and amylase production, with this carbon source. This amount of cell yield and amylase production was much higher than what was obtained in the presence of starch, which is known as the general substrate for amylase production. Hiller et al. (1997) demonstrated a similar enhanced cell growth and $\alpha$-amylase production by Ba-

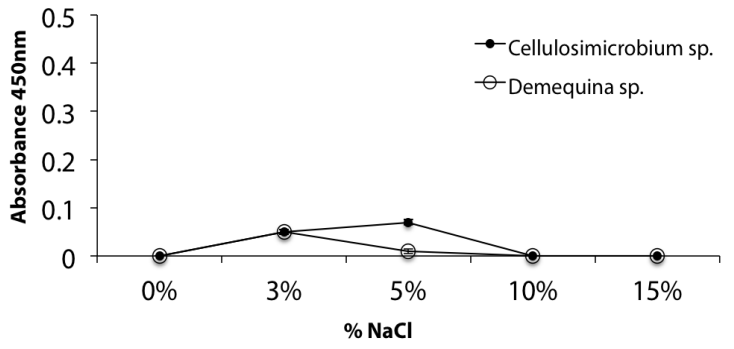

Figure 6. Effect of salt concentration on amylase production of Cellulosimicrobium sp. and Demequina sp. $(\lambda 540 \mathrm{~nm})$. The data are the means of two replicates \pm standard deviation. 


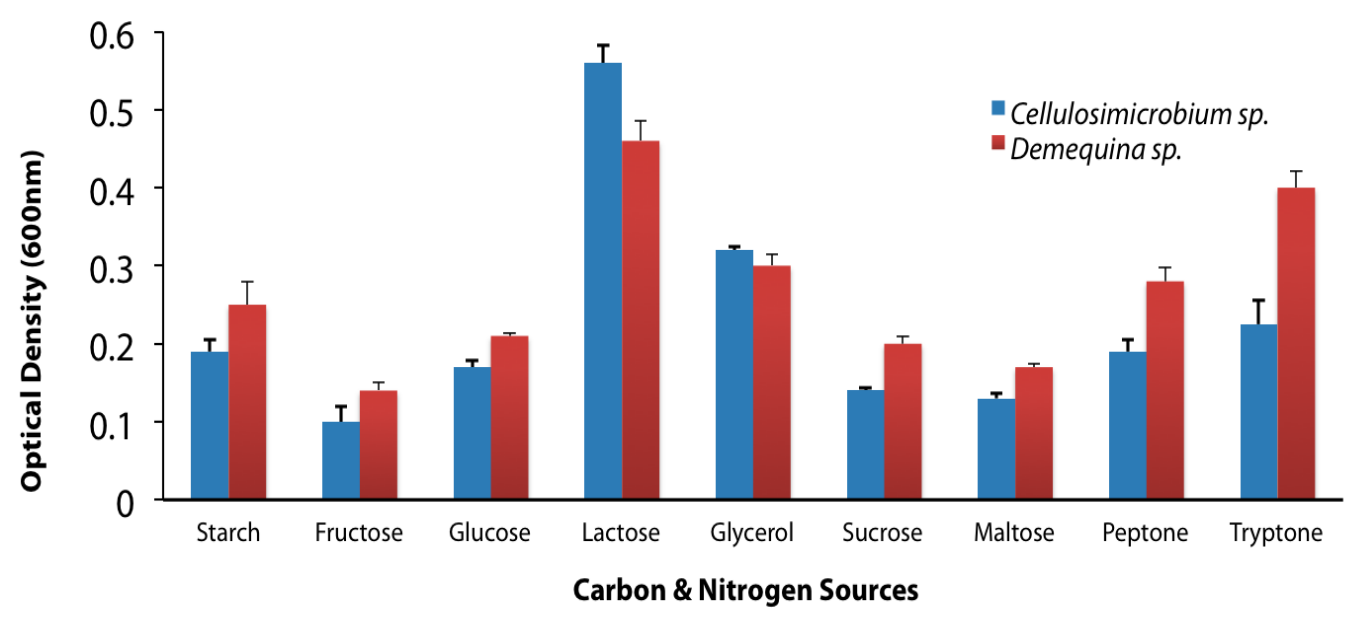

Figure 7. Effect of carbon and nitrogen sources on cell yield of Cellulosimicrobium sp. and Demequina sp. $(\lambda=600 \mathrm{~nm})$. The data are the means of two replicates +1 standard deviation.

cillus amyloliquefaciens from lactose. The lowest bacterial growth and enzyme secretion was observed in the presence of fructose. Glucose was found to yield very minimum amounts of amylases from both of the bacterial strains regardless of its effect on cell growth. Repression of amylase synthesis by glucose was also reported in thermophilic and alkaliphilic Bacillus sp. TS-23 (Lin et al., 1998), Sulfolobus solfataricus (Haseltine et al., 1996) and Bacillus sp. isolate L1711 (Bernhardsdotter et al., 2005). Haseltine et al. (1996) justified that glucose prevents gene expression of $\alpha$-amylase and represses its secretion. Although maximum cell growth of Demequina sp. was obtained in the presence of lactose, the highest enzyme production was induced by fructose and glycerol (Figure 8). Glycerol was reported to increase enzyme production in Bacillus sp. PS-7 (Tanyildizi, 2005) and Bacillus sp. I-3 (Goyal, 2005).

Higher optical density was obtained in the presence of tryptone which indicates that it enhanced the cell growth of both strains more than peptone (Figure 9 \& $10)$. However, more maltose was produced by the addition of peptone which reflected its higher stimulation of amylase production. The decrease in the amounts of maltose as the end product of starch hydrolysis in the presence of tryptone may be due to the intolerance of the bacterial strains to $0.5 \%$ tryptone. Similar results were reported previously (Chakraborty et al. 2008a). These authors found a decrease in amylase production by Saccaropolyspora species A9 at tryptone concentrations beyond $0.4 \%$.

\section{Conclusions}

Two amylases were isolated from the two bacterial strains Cellulosimicrobium sp. and Demequina sp., which were correspondingly obtained from the green

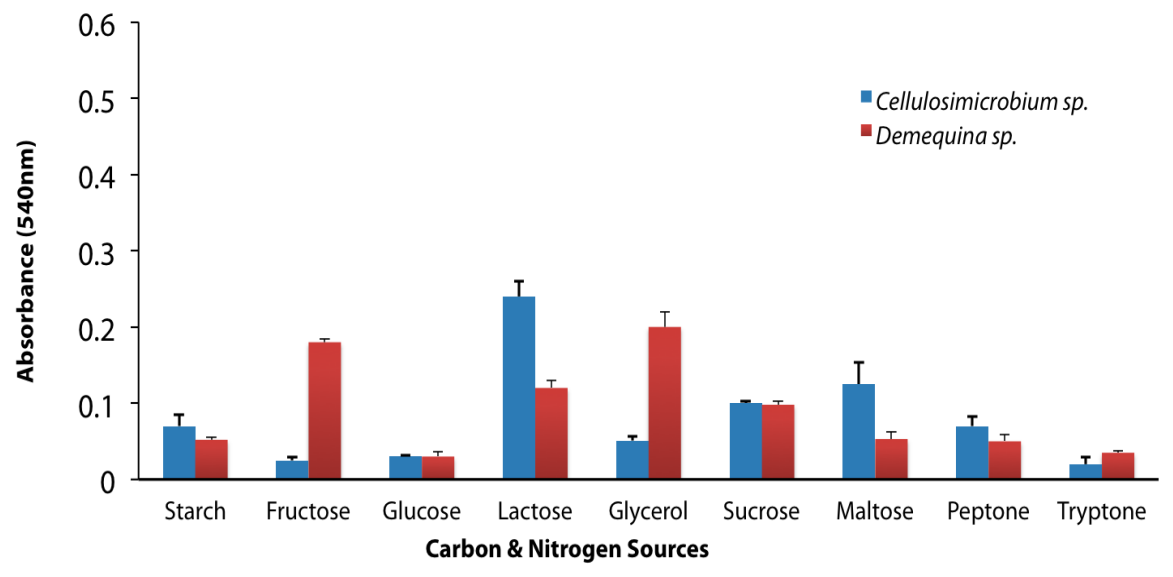

Figure 8. Effect of carbon and nitrogen sources on amylase production of Cellulosimicrobium sp. and Demequina sp. $(\lambda=$ $540 \mathrm{~nm}$ ). The data are the means of two replicates +1 standard deviation. 


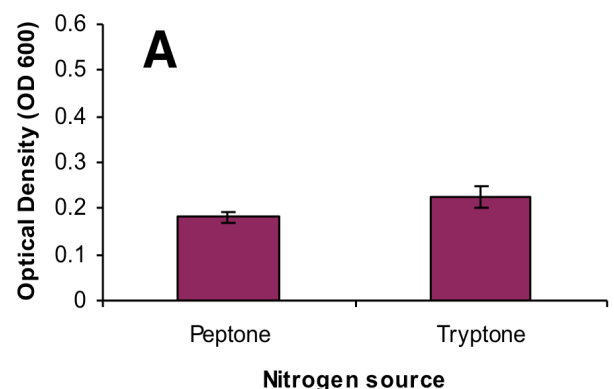

B

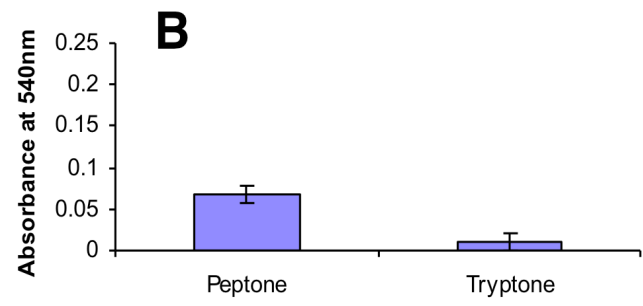

Figure 9. (A) Effect of nitrogen source on cell yield of $\mathrm{Cel}$ lulosimicrobium sp. measured at $\lambda=600 \mathrm{~nm}$. (B) Effect of nitrogen source on amylase production by Cellulosimicrobium sp. measured at $\lambda=540 \mathrm{~nm}$. The data are the means of two replicates \pm standard deviation.

alga Ulva rigida and the sponge Mycale sp. Maximum cell yield from the two bacterial strains was obtained at temperatures between $29^{\circ} \mathrm{C}$ and $35^{\circ} \mathrm{C}$ and $3 \%$ salinity, which indicate that the two strains have mesophilic and halophilic properties. Addition of lactose and tryptone significantly increased the growth of both of the strains. Both strains produced highest amount of amylase at temperatures between $29^{\circ} \mathrm{C}$ and $35^{\circ} \mathrm{C}, 3 \%$ salinity and in the presence of peptone. Addition of lactose increased amylase production by Cellulosimicrobium sp., whereas supplementation of the media with fructose and glycerol resulted in maximal amylase production by Demequina sp. The present study demonstrated that all eight investigated marine organisms are promising sources of amylases producing bacteria. This finding provides the possibility to isolate more enzymes-producing bacteria and search for novel bioactive compounds from the marine environment in Oman.

\section{References}

DeeAsgher, M., M. J. Asad, S. U. Rahman, and R. L. Legge. 2007. A thermostable amylase from Bacillus subtilis strain for starch processing. Journal of Food Engineering 79: 950-955.

Bernhardsdotter, E. C. M. J., J. D. Ng, O. K. Garriott, and M. L. Pusey. 2005. Enzymic properties of an alkaline chelator-resistant amylase from an alkaliphilic Bacillus sp. isolate L1711. Process Biochemistry 40:24012408.

Brown, J. M., A. G. Steigerwalt, R. E. Morey, M. I. Dane-
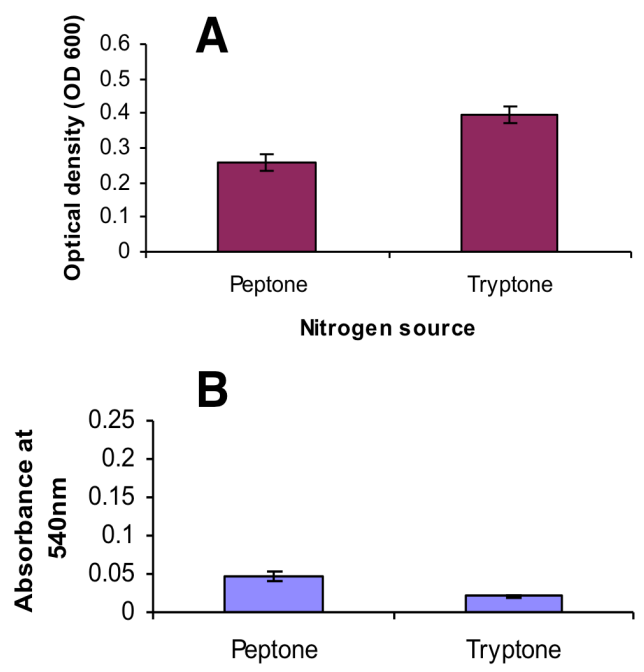

Figure 10. (A) Effect of nitrogen source on cell yield of $D e$ mequina sp. measured at $\lambda 600 \mathrm{~nm}$. (B) Effect of nitrogen source on amylase production by Demequina sp. measured at $\lambda=540 \mathrm{~nm}$. The data are the means of two replicates \pm standard deviation.

shvar, L. Romero, and M. M. McNeil. 2006. Characterization of clinical isolates previously identified as Oerskovia turbata: proposal of Cellulosimicrobium funkei sp. nov. and amended description of the genus Cellulosimicrobium. International Journal of Systematic and Evolutionary Microbiology 56: 801-804.

Chakraborty, S., A. Khopade, C. Kokare, K. Mahadic, and B. Chopade. 2008a. Isolation and characterization of novel amylase from marine Streptomyces. Journal of Molecular Catalysis 10: 1-31.

Chakraborty, S., A. Khoqade, Rinbio, X.Y. Liu, L. Zhang, K. Mahadic and C. Kokare. 2008b. Isolation, partial purification and characterization of halophilic, alkali tolerant, thermostable, surfactant and detergent stable amylase enzyme from marine Saccharoplyspora species. Marine Biotechnology 11:1-35.

Heym, B., P. Gehanno, V. Friocourt, M. Bougnoux, M. Le Moal, C. Husson, J. Leibowitch, and M. Nicolas-Chanoine. 2005. Molecular detection of Cellulosimicrobium cellulans as the etiological agent of a chronic tongue ulcer in a human immunodeficiency virus-positive patient. Journal of Clinical Microbiology 43(8): 4269-4271.

Funke, G., C. P. Ramos, and M. D. Collins. 1995. Identification of some Clinical Strains of CDC Coryneform Group A-3 and A-4 bacteria as Cellulomonas species and proposal of Cellulomonas hominis sp. nov. for some Group A-3 Strains. Journal of Clinical Microbiology 33(8): 2091-2097.

Goyal, N., J. K. Gupta, and S. K. Soni. 2005. A novel raw starch digesting thermostable $\alpha$-amylase from Bacil- 
lus sp. I-3 and its use in the direct hydrolysis of raw potato starch. Enzyme Microbiological Technology 37: 723-734.

Harumi Ue, H., Y. Matsuo, H. Kasai, and A. Yokotam. 2011. Demequina globuliformis sp. nov., Demequina oxidasica sp. nov. and Demequina aurantiaca sp. nov., actinobacteria isolated from marine environments, and proposal of Demequinaceae fam. nov. International Journal of Systematic and Evolutionary Microbiology 61(6): 1322-1329.

Haseltine, C., M. Rolfsmeier, and P. Blum. 1996. The glucose effect and regulation of $\alpha$-amylase synthesis in the hyperthermophilic archaeon Sulfolobus solfataricus. Journal of Bacteriology 178: 945-950.

Hiller, P., D. A. J. Wase, A. N. Emergy, and G. L. Solomon 1997. Instability of -amylase production and morphological variation in continuous culture of Bacillus amyloliquefaciens is associated with plasmid loss. Process Biochemistry 32: 51-59.

Kathiresan, K., and S. Manivannan. 2006. Amylase production by Penicillium fellutanum isolated from mangrove rhizosphere soil. African Journal of Biotechnology 5(10): 829-832.

Lau, S. C. K., K. K. W. Mak, F. Chen, and P. Y. Qian. 2002. Bioactivity of bacterial strains from marine biofilms in Hong Kong waters for the induction of larval attachment in the marine polychaete Hydroides elegans. Marine Ecology Progress Series 226: 301-310.

Lin, L. L., C. C. Chyau, and W. H. Hsu. 1998. Production and properties of a raw-starch-degrading amylase from thermophilic and alkaliphilic Bacillus sp. TS-23. Biotechnology and Applied Biochemistry 28: 61-68.

Mohapatra, B. R., U. C. Banerjee, and M. Bapuji. 1998. Characterization of a fungal amylase from Mucor sp. associated with the marine sponge Spirastrella sp. Journal of Biotechnology 60: 113-117.

Mohapartra, B. R., M. Bapuji, and A. Spree. 2003. Production of industrial enzymes (Amylase, Carboxymethy and Proteanes) by bacteria isolated from marine sedentary organisms. Journal of Acta Bio- technology 23:75-84.

Moore, B. S. 1999. Biosynthesis of marine natural products: microorganisms and Macroalgae. The Royal Society of Chemistry 16: 653-674.

Prakash, B., M. Vidyasagar, M. S. Madhukumar, G. Muralikrishna, and K. Sreeramulu. 2009b. Production, purification and characterization of two extremely halotolerant, thermostable, and alkali- stable amylases from Chromohalobacter sp. TVSP 101. Process Biochemistry 44: 210-215.

Proksch, P., R. Edrada, and R. Ebel. 2002. Drugs from the seas - current status and microbiological implications. Applied Microbiology and Biotechnology 59(2): 125-134

Sasser. 1990-revised 2001. Identification of Bacteria by Gas Chromatography of Cellular Fatty Acids. MIDI, Technical Note \#101.

Vidyalakshmi, R., R. Paranthaman, and J. Indhumathi. 2009. Amylase production on submerged fermentation by Bacillus spp. World Journal of Chemistry 4 : 89-91.

Yi, H., P. Schumann, and J. Chun. 2007. Demequina aestuarii gen. nov., sp. nov., a novel actinomycete of the suborder Micrococcineae, and reclassification of Cellulomonas fermentans Bagnara et al. 1985 as Actinotalea fermentans gen. nov., comb. nov. International Journal of Systematic and Evolutionary Microbiology 57(1): 151-156.

Yoon, J., S. Kang, P. Schumann, and T. Oh. 2007. Cellulosimicrobium terreum sp. nov., isolated from soil. Journal of Systematic and Evolutionary Microbiology 57: 2493-2497. 